\title{
Graphology in Germany in the 1920s and 1930s
}

\section{Amateurs, Psychologists, and the Police on the Scientific Nature of Graphology}

\author{
Laurens Schlicht
}

\begin{abstract}
In this article I examine how psychologists, amateurs and actors in the police and in juridical fields positioned themselves in the 1920s and 1930s on the scientific nature of graphology. Graphology, the study of the character from handwriting, was linked with the hope of providing reliable methods for the investigation of psychological states and dispositions. The essay argues that on an epistemic level two different models have been represented to support the scientific nature of graphology: for one thing resorting to the special individual skill, the "genius" of a graphologist; or rather depersonalized techniques predominantly based on statistics. Amateur graphologists used both of these forms.

On a methodological level, I argue that in order to historicize the human sciences in general, and psychology in particular, it is useful to examine the translation processes that turn everyday interpretative practices (of facial expressions, dreams, handwriting) into scientific legitimate investigative procedures. In order to investigate precisely this translation process, it is useful to look at what Thomas Gieryn calls "boundary work" at the border between scientific and non-scientific interpretation practices, for which graphology is used here as an example. It is particularly illuminating to examine how representatives of the official sciences distinguish themselves from presumed "charlatans", which is why the article focuses on court cases and the demarcation strategies used by the police against fraudulent amateur graphologists.
\end{abstract}

Keywords: Graphology, History of the Human Sciences, Weimar Republic, National Socialism, History of Psychology

Graphologie in Deutschland in den 1920ern und 1930ern. Amateur*innen, Psycholog*innen und die Polizei über die Wissenschaftlichkeit der Graphologie

In dem Aufsatz wird untersucht, in welcher Weise sich Psycholog*innen, Amateur*innen und Akteur*innen der Polizei und des Rechtswesens in den 1920er und 1930er Jahren zur Wissenschaftlichkeit der Graphologie positioniert haben. Mit der Graphologie, der Lehre von der Deutung der Handschrift als Ausdruck des Charakters, war die Hoffnung verbunden worden, zuverlässige Methoden zur Untersuchung psychischer Zustände und Dispositionen zur Verfügung zu haben. In dem Aufsatz wird argumentiert, dass auf epistemischer Ebene zwei verschiedene Modelle vertreten worden sind, um die Wissenschaftlichkeit der Graphologie zu untermauern: zum einen der Rekurs auf eine spezielle persönliche Eignung, das "Genie", des Graphologen, zum anderen entpersonalisierte, zumeist statistisch gestützte Techniken. Die Amateurgraphologen haben sich auf beide Formen bezogen.

Auf methodologischer Ebene argumentiere ich, dass es zur Historisierung der Wissenschaften von der Psyche im Allgemeinen und der Psychologie im Besonderen nützlich sein kann, den Übersetzungsprozess zu untersuchen, der aus alltäglichen Deutungspraktiken (wie etwa des Gesichtsausdrucks, von Träumen, der Handschrift) wissenschaftlich legitim erscheinende Untersuchungsverfahren macht. Um genau diesen Übersetzungsprozesses zu untersuchen wird das "boundary work" (Thomas Gieryn) an der Grenze von wissenschaftlichen und nicht-wissenschaftlichen Deutungspraktiken am Beispiel der Graphologie betrachtet. Dabei erweist sich als besonders aufschlussreich zu untersuchen, wie sich vertreter*innen offizieller Wissenschaften von den mutmaßlichen „Scharlatanen” abgrenzten. Der zentrale Quellentypus, auf dem der Artikel beruht, sind deshalb Gerichtsprozesse gegen Amateurgraphologen, denen Betrug vorgeworfen wurde, in denen explizit gemacht werden musste, was die Wissenschaftlichkeit von Graphologie ausmachte. 
Paul Papst considered himself a "psychologist," and thus capable of understanding the character and the inclinations of men and locating the latter in the brain. ${ }^{1}$ That much he explained to the law enforcement authorities during his interrogation for fraud. Albert Hellwig, a judge and prominent author of research on peripheral scientific areas (such as occultism or parapsychology) provided an expert testimony for Papst's trial in 1924. His expert opinion reflects the self-portrayal of Papst in his interrogation:

Paul Papst calls himself a psychologist. During his responsible interrogation he stated that he worked as a graphologist and phrenologist as well as in the fields of biochemistry, suggestion and occultism. By graphology he understood the study of writing for the assessment of characters, the nervous system and the life of the soul. By psychology he understood the evaluation of the character and the inclinations of men respectively their localization in the brain. By biochemistry he understood the healing treatment using chemical salts. By suggestion he understood the influencing of the state of the soul for the healing of emotional and similar ailments. He said that he acquired the knowledge in this field by studying scientific writings. ${ }^{2}$

From the 1920s Germany onwards, graphology - the science of inferring the character of a person from the peculiarities of her or his handwriting-typically was a case of discussing what constitutes the legitimacy of scientific practices for evidencing the mind or the character of human beings. Since graphology made knowledge claims about mental states-the "mind," "intentions," "character"-especially psychologists either proclaimed their own scientificity by distancing themselves from graphology, or further developed their own versions of graphology. Graphology thus became a field of knowledge triggering discussions, which practices could legitimately generate knowledge about the character, personality, or intentions of persons (for the sake of shortness I will call them "evidence techniques" in the following). In this respect, graphology competed with a number of more or less old methods of accessing the human mind by analysing its physical artefacts, like phrenology, psychological methods of expression analysis (facial expression, gestures, etc.), and commercial approaches to determine the "character" or "personality" of possible employees pursued by psychotechnics (cf. Jaeger 1985). In terms of Carlo Ginzburg, it can be said that graphology also followed the 
increased interest in social classification, which in turn was linked to the growing need for differentiating types of human labour (Ginzburg 2002).

In this article I demonstrate how psychologists, jurists, and non-scientific actors used graphology as an evidence technique. I will show that during the period investigated here, at least two ways existed for psychologists to demarcate their expertise as scientists at epistemic level: the first can be called the "medical" model, and is built upon the figure of the graphological genius. This model, which is exemplified by Roda Wieser (1894-1986), Friedrich von Rohden (1886-1959), and Ludwig Klages (1872-1956), argues that it was possible and actually necessary to have some form of graphological training based on some experimental knowledge or systematic differentiation of expression, but that still a good graphologist needed "intuition". The second model is the "statistical" model. The psychologist Karl Marbe (1896-1953) in particular argued that only by establishing statistical correlations graphology could possibly gain solid footing. This approach relied on a depersonalized concept of knowledge that dispensed with the person of the interpreter. A third model not to be analysed in this article was the figure of the graphological medium, which was especially relevant for the Zeitschrift für Parapsychologie; the neurologist and psychoanalyst Johannes Marcinowski (1868-1935) wanted to establish a form of "meta-graphology" that could only be carried out by mediumistically talented persons, and could be used for both, character analysis as well for a range of seemingly otherworldly knowledge (cf. for example Marcinowski 1926; 1928: 648).

Secondly I want to highlight actors who are commonly excluded from the scrutiny of scholarly attention: amateur graphologists, who offered their services in non-scientific spaces, such as funfairs, pubs. I want to show that with regard to these actors in particular, the question of the scientific nature of evidence techniques required discussion and specific proposals for practical solutions. For this purpose I will draw on court cases conserved in the papers of Albert Hellwig (1880-1950) in the Freiburg Institute for Frontier Areas of Psychology and Mental Health (IGPP), and in the Karl Marbe papers conserved at the Adolf-Würth-Zentrum of Würzburg University as well as on additional archival sources from the Staatsarchiv Leipzig as well as some documents from the Otto Lipmann and William Stern papers conserved in The National Library of Israel in Jerusalem. The evidence, which can be traced in Hellwig's and Marbe's papers about the nature of the practices of amateurs are sketchy, but, cautiously interpreted, they can nevertheless provide some insight into the use of graphology outside the academic universe of texts and practices. Then again, the court cases allow analysing the ways psychologists or psychologically trained jurists like Hellwig used to document their understanding of science with juridical 
vigour: experts defending the scientificity of psychology had to distinguish themselves from amateur practitioners by rendering their understanding of what constitutes proper science explicit. Therefore, we can understand here, why and how these psychologists believed in the superiority of their practices of interpreting bodily expressions, and specifically handwriting. A third type of material are archival sources on police practices to control graphologists from the Staatsarchiv Leipzig. ${ }^{3}$ They largely confirm the statements of psychologists and jurists that graphology remained at the interface between scientific and non-scientific practices of character diagnosis, and that is precisely why it triggered a discussion in the police.

Based on these analyses I will argue that graphology has to be characterized as a paradigmatic case starting from which scientific and nonscientific actors negotiated the nature of science, the legitimacy of belonging to a scientific community, and the reliability of the means to know a person's character. Due to the interacting of everyday practices, exigencies before court, and the quest for scientification graphology is a typical case for discussing the boundaries of science-a prime example for what Thomas Gieryn has called "boundary work" (Gieryn 1983).

Graphology is often and rightly associated with the name Ludwig Klages. As research has shown, Klages was the leading figure for the Germanspeaking world regarding graphology (Lebovic 2013). For example Emil Utitz, a Jewish psychologist and characterologist, described Klages in 1925 as the "brilliant leader" of graphology (Utitz 1925: 31). Mitchell Ash has pointed out that the methods of Klages were actually introduced in personnel administrations in the 1920s (Ash 2002: 235). Students and admirers of Klages like Philipp Lersch (1898-1972, see Gesicht und Seele, 1932) became central figures of characterology in the "Third Reich". Thus, graphology, rooted in characterology, was also part of a culturally conservative, anti-Semitic, and racist theoretical movement that later proved to be extremely attractive to the Nazis. But to emphasize only this aspect would hide the fact that there was also an important Jewish tradition of characterology and graphology (see Lebovic 2013). The two historical roots of scientific graphology-experimental physiology and characterology-thus formed political-epistemic reference points to format the status of the respective versions of graphology.

The article is divided into four parts and a concluding section. In the first part I clarify the perspective from which I want to study graphology. In the second part I will discuss three selected court cases of amateur graphologists, who were accused of fraud. The third part treats one reaction to the widespread practice of graphological institutes in the 1920s in the consulting of enterprises and private individuals. The fourth part then discusses reactions of Leipzig police headquarters in charge of the laws 
prohibiting clairvoyance, and hence had to decide whether graphological practices were actually scientific or fraudulent. In the concluding section I will discuss a possible approach to explain why graphology became such a locus classicus for discussing boundaries of science and the techniques interpreting human expression.

\section{Research}

Research on the history of graphology so far has been scarce. There is the nineteenth-century history of graphology that is not relevant for the scope of this article (Vars 1874). Notes on the history of graphology can as well be found in contemporary treatments of the subject which are, however, not sufficiently detailed and highly biased. ${ }^{4}$ Recent research on the history of graphology focuses on its use in psychiatry (Schäfer 2016), and on the discussion between Alfred Binet (1857-1911) and Jules Crépieux-Jamin (1859-1940) (Nicolas et al. 2015). Nitzan Lebovic's research is relevant for a reassessment of the role of Ludwig Klages and characterology (Lebovic 2013).

One highly interesting article by Caspar Hirschi deals with the court case on Alfred Dreyfus in 1894. During the Dreyfus affair, as Hirschi points out, graphological expert testimonies played a crucial part, since one major question was if the so called "bordereau," the unsigned and undated intelligence note addressed to the German military attaché in Paris, Max von Schwartzkoppen (1850-1917), had been written by Dreyfus or not (Hirschi 2016). His article provides some insight into the history of experts for handwriting as well dating back to the late sixteenth century (ibid.: 710) and that graphology was introduced as a science by Jan Hippolyte Michon in 1875 (ibid.: 713). He comes to the conclusion that after the Dreyfus affair graphology became discredited as a science, and was rather practised in the spheres of private enterprises, used by "managers and head hunters" (ibid.: 743). Some details of Hirschi's fascinating and insightful new interpretation of the Dreyfus affair might nevertheless be questioned from the history of science standpoint: one can agree with Hirschi that graphology was not always clearly a scientific discipline in the first half of the twentieth century. Then again, the following examples will show that the Dreyfus affair was not "the beginning of the end of [graphology's] aspiration to be recognized as an exact science" (ibid.). 


\section{Graphology as a Pseudoscience?}

Graphology was one of many methods of interpreting bodily expression in order to learn something about the psyche or the mind. Since the late eighteenth century, various actors have tried to render these methods scientific. These methods can be distinguished into self-observation and external observation. There is little research on the history of self-observation (regarding nineteenth-century France, cf. Braunstein 1998). Since the early nineteenth century a number of techniques have been used for the scientific study of body interpretation (cf. Courtine \& Haroche 1994; Schmölders 1995). A well-known technique is phrenology (measurement of the skull to determine character traits and intelligence), whose prominent representatives were the physicians Franz Joseph Gall (1758-1828) and Johann Spurzheim (1776-1832) (cf. Wyhe 2002). Another technique was physiognomy, which is strongly connected to the name of Johann Caspar Lavater (1741-1801) (cf. Bindman 2002: 92 ff.; for the later history of the analysis of emotions based on facial expressions in the twentieth century, Leys 2010). In comparison with these evidence techniques, graphology was quite late in trying to establish a canon of scientific norms and procedures, which was particularly advanced by Jean-Hippolyte Michon (1806-1881) (cf. Vars 1874; Nicolas et al. 2015; Hirschi 2016). ${ }^{5}$

In the second half of the nineteenth century, experimental psychology and psychiatry also gave rise to fields of enquiry that provided various measurement methods for the analysis of physical expression; this later led to the measurement of "brain waves" with electroencephalography (cf. Borck 2015). With the establishment of psychology as an academic discipline in the late nineteenth century, these new approaches opened up a frame of reference to which graphology also had to relate. In the period discussed here, graphology behaved ambivalently, alternating between more hermeneutic or phenomenological evidence techniques, and more statistical and instrumentally supported ones. In the psychiatric field, the kymograph-based method of capturing human expression in the form of curves on carbon black paper was linked to graphology. Against this background handwriting was also sometimes called "brainwriting", with reference to the documentation of a state of mind by a natural curve in the form of writing (Preyer 1928; Pophal 1949; Schäfer 2016: 309).

Based on different models of the human psyche, psychology was interested in handwriting in the context of other methods of expression analysis, which were then extensively used in Wehrmacht psychology (cf. Geuter 1983, 1985; Hofstätter 1940). Hence Austrian psychologist Peter Hofstätter (1913-1994) used graphology, for example, in his experiments with the "dark writing" (Dunkelschrift): by analysing handwriting produced 
in the dark Hofstätter sought to present a method of making the expression of writing unaffected by other influences.

There has been too little discussion in recent decades about how to write an epistemic history of evidence techniques. A theoretical framework has been provided by Ian Hacking to analyse the process of differentiation between subject constructions and subjects constructed (Hacking 1999; 2002). In his empirical study about the development of the subject category of the "abused child" Hacking, for example, highlighted the institutional, political, and social logics with which this process of the establishment of institutions and subject strategies of "child abuse" became interrelated (Hacking 1991). He argued that new forms of being a person had been invented, which had unfolded in a complex interplay of conceptual attribution and self-interpretation (Hacking 1986).

With this article I want to contribute to the historical analysis of epistemic techniques to investigate mental states, or what Jan Goldstein has called the "mental stuff", that is, all kinds of objects or states (like mind, psyche, intentions, fears) that is represented in the vocabulary to talk about psychic things (Goldstein 2005: 2) -called evidence techniques in this article. I argue that it is a methodologically compelling option for analysing the professionalisation strategies of evidence techniques in psychology to investigate knowledge fields that are represented both in- and outside the esoteric circles of science, like the interpretation of facial expression, dreams, and graphology. Yet, the epistemic structure of psychology is characterized by the fact that it not only introduces new concepts or practices for interpreting behaviour or mental states but also reinterprets familiar ones. Graphology undoubtedly belongs to the latter. Analysing this part makes it necessary not to investigate the birth of an epistemic, social, or political object in historical ontology but rather to make visible the translations that enabled psychology and other human sciences to incorporate concepts from ordinary language and everyday practice into the canon of science.

Graphology was lively discussed in the first half of the twentieth century, and also after 1945. If one believes Siegfried Kracauer (1889-1966) and his famous study about The Salaried Masses (Die Angestellten), graphology was widely used by enterprises to select higher employees (Kracauer 1971 [1930]: 222). But at least in Germany and France (cf. Binet 1903), acknowledged experts also pursued graphology from the 1920 s to the 1960 s, such as for instance the psychiatrist Rudolf Pophal (1893-1966), who started lecturing on graphology at Greifswald University in 1939.6 Also William Stern (1871-1938), director of the renowned Institute for Psychology of Hamburg University emphasized in 1931 that alongside psychotechnical analyses of the human performance, the character should likewise be studied with the help of graphology (Stern 1931: 15). The report on the first post-war 
meeting of German psychologists disclosed that of the altogether 31 papers delivered, six were on graphology (Bornemann \& Bornemann 1948). When psychologist Franziska Baumgarten (1889-1970) criticised graphology in 1950 for lacking an objective foundation, she received a letter from a friend in Tel Aviv, in which he put graphology on a par with all other methods of expression analysis. ${ }^{7}$ And when in 1952 psychologist and visiting professor at Harvard University Helmut von Bracken reported on the new developments of German psychology, he underlined that graphology was an important part of psychological research, forming part of the analysis of "expressive movement," referring to the works of Klages and Lersch among others (Bracken 1952: 172). In 1960 the Heidelberg Institute for Psychology hosted a graphologists conference, which was attended by over 100 participants. It also offered teaching positions for graphology since 1952 (Jung 2000: 48-60). In 1962 Friedrich Koppe pointed out that "graphology has already overcome its pre-scientific stage for over half a century" and that it constituted to be a teaching subject at German universities (Koppe 1962: 103).

If you look at bibliographical data from the Bibliothèque nationale (Paris), from the catalogue of Harvard Library, and from Deutsche Nationalbibliothek, searching for books with the word "graphologie" resp. "graphology" in the title, we can see some indications for the development of graphology. Based on this bibliometric data, the general picture is not uniform: In Germany you have an average of 32 (31.9) books per ten years with a climax in the decade from 1950-1960 (51), whereas there are as well 46 and 43 books published in the decades of the 1920s and 1930s, which compared to a supposed smaller total number of books published might also be read as boost. The most important platform for dealing with graphological questions was the Zeitschrift für Menschenkunde (und Zentralblatt für Graphologie) first was published in 1925. In France the average of published books is 33.6 per ten years with a climax in 1970s (70 books), whereas here we do not see a climax in the 1920s and 1930s. The Hollis Catalogue of Harvard University provides us with an average of 7.5 books per ten years with a climax from 2000-2010 (18 books).

Should graphology therefore be historically reconstructed in terms of a "pseudoscience" (cf. Rupnow et al. 2008)? The previous examples show that graphology has been discussed and practised as a regular candidate for character analysis amongst psychologists and psychiatrists. Even if actors outside graphology may have considered it as pseudoscience, the esoteric discourse of psychology during the period investigated was focused rather on the question, how exactly graphology could be defined as an "exact" or "objective" scientific discipline. ${ }^{8}$ This is also true when we consider the justified criticism of Ludwig Klage's anti-intellectualism and his proxim- 
ity to National Socialism. According to Tobias Schneider, Klages' book on graphology has been one of the biggest bestsellers on the non-fiction book market during National Socialism (Schneider 2001: 292). His emphasis on the intuition of the graphological genius must be seen as part of his antiintellectualism and in the context of his anti-Semitic worldview (ibid.: 276). Since Klages' name is strongly connected with graphology in Germany, a legitimate rejection of Klages could easily evoke the view that graphology as a whole must be equated with National Socialist pseudoscience. Without intending to defend graphology nor underlining its un-scientific nature, I want to indicate the fact that graphology constituted a part of ordinary psychological (and also psychiatric, cf. Schäfer 2016) research, and while Klages' anti-intellectual, anti-Semitic, anti-parlamentarist, anti-liberal, and anti-Marxist inclinations are part of his graphological reflexions, graphology as such was not characterized by a clear-cut political or ideological commitment. ${ }^{9}$ The reference to pseudoscience or systems hostile to science has, on a larger scale, for a long time made it more difficult to carry out thorough epistemic analyses. Research has shown that after 1945 psychologists argued that National Socialism was hostile towards psychology, and that the discipline was suppressed during this period (see Prinz 1985: 89-90). This narrative is not well-suited to reflect on the past of one's own discipline. To qualify something as pseudoscience can thus easily result in an unsystematic examination of a historical constellation of knowledge production. This is true for the case of graphology: In the positivity of the historical material, graphology emerges as a method of expression analysis amongst many alternatives; a method rejected by some but further developed by others as a promising option for character analysis.

Unlike para-psychology, telepathy or occultism, graphology relied on widespread and accepted practices of interpretation. It was by no means unusual to draw conclusions about the character of a person from the handwriting. There was greater disagreement about the forces, properties, and objects studied in parapsychology. In the case of knowledge fields such as parapsychology there was disagreement about the very existence of these things - for example inexplicable contacts of two minds - , about fundamental assumptions regarding the ontology of the world. In the case of graphology, the actors presented in this article disagreed only as to whether and how this widespread interpretation technique could become scientific. 


\section{Graphology as Everyday Practice}

Albert Hellwig, the examiner of Paul Papst already mentioned in the beginning, was an acknowledged expert for the field of diverse practices on the edge of official science: occultism, mind reading, clairvoyance, and also graphology. ${ }^{10}$ As a judge and expert he was involved in many cases related to these practices, mostly due to charges of fraud, and he composed influential texts on the subject in the 1920s (Hellwig 1924; 1929). Said practices were tolerable to varying degrees. Clairvoyance was mostly regarded as charlatanry, occultist practices and mind-reading were already controversial and possibly be regarded as sciences. In Hellwig's view, regarding the scientific nature of graphology the matter was rather uncontroversial, because at least some of its forms were firmly integrated into the canon of science. By referring to graphology, those accused of fraud could claim a socio-epistemic status, which legitimised them in the eyes of their clients.

My first example for this is a court case of 1924: A Russian woman was imprisoned in Siberia for four years after the Russian Revolution of 1917. Following her imprisonment in Siberia and five month of famine in Riga she migrated to Germany where she hoped to make a living for herself and her two daughters. During her interrogation she stated that she thought that the profession of a graphologist would help her to achieve this, while in effect she then offered chiromancy (the art of reading hands) and cartomancy (the art of reading the future out of cards) as well. Hellwig recorded her interrogation as follows:

By graphology Mrs. Zinserling-Sino understands, according to the information she gave during her interrogation, the study of handwriting in the direction of the lines, the endurance, the placement of the letters, the beginning of the letters, closed or open letters, the direction of the individual characters, the marking of the name. She had already studied in younger \{years\} graphology by herself, and then trained further during a four-year internment in Siberia under the guidance of the son of Professor Mang in Heidelberg. ${ }^{11}$

Since it was well-known that graphology was conducted by credible professionals and had "undeniably a scientific basis," ${ }^{2}$ Hellwig wrote in his expert testimony, Zinserling-Sino suggested that her practices were based on a reliable basis as well. She suggested to her customers that she worked on a scientific basis. In the legal system of Weimar Republic this generated the right of customers to be protected, hence Zinserling-Sino had to prove in court that her knowledge in graphology was adequate. In principle, Hellwig hereby displayed openness and for example in the case of two female clairvoyants conducted experiments himself to test their reliability. ${ }^{13}$ In the 
specific case of Zinserling-Sino, however, Hellwig decided that her vague statements about graphology and her alleged studies were not sufficient prove that she had "penetrated the spirit of this science."14 Hellwig further substantiated his unfavourable opinion by contacting a certain "Professor Mang," whom he identified as "sports writer and university scholar" (Sportschriftsteller und Universitätsgelehrter). Mang in fact affirmed that he had been interned with Zinserling-Sino in Siberia, but did not remember having taught her graphology on a regular basis. Also, he had no textbooks on graphology with him during the imprisonment. As will be shown in the police section, these tests were typical markers for the juridical system to validate the scientificity of a given dubitable practice by establishing if Zinserling-Sino has received a proper training in graphology or read acknowledged scientific literature. Hellwig's negative assessment was further strengthened by the fact that she practised graphology together with cartomancy and chiromancy. ${ }^{15}$

This assessment was not necessarily shared by the graphologists' clients-among them eminent figures. Hence another female graphologist also accused of fraud, who ran a "scientific graphological-astrological institute", regularly advised a priest in employment matters. The priest testified:

I have been made aware of Madame Gr[ude] by a lady completely unknown to me, with whom I shared a restaurant table in Erfurt by pure chance, and with whom I talked about the interpretation of handwriting, graphology, etc. ${ }^{16}$

He then underlined that Grude worked "quite decidedly on a scientific basis," that she was an honest person who worked for the "good and true," and that her graphological expert opinions had always been correct. ${ }^{17}$ In a letter to Hellwig, Grude herself announced that she could name "higher court officers" who used her services when required, from which she would, however, distance herself as long as possible from for reasons of discretion. ${ }^{18}$

The discussion about fraud reappears in the papers of Karl Marbe, who was professor of psychology at Würzburg University. ${ }^{19}$ He was regarded as another eminent expert for the discussion on border areas of science. In Hellwig's papers we also find a reference to Marbe: the defence in a clairvoyance trial referred to Marbe, because he appreciated Marbe's work on the divining rod. ${ }^{20}$ In this 1928 case the defence judged clairvoyance as a promising option for which the state should offer formalised training. ${ }^{21}$

In 1927 the rectorate of Würzburg University received a letter from the "Bezirksamt" (district office) of Wolfach in Southern Germany in a court case against a self-proclaimed graphologist who offered interpretations of 
the character based on handwriting (for 1 Mark, which was significantly cheaper than the expert opinions of graphological institutes ranging from 15 to 30 Mark). This graphologist referred to Würzburg University and claimed that there existed a chair for graphology. Although he did not pretend having studied there, he thus wanted to emphasize the scientific character of graphology as a practice. He testified:

I am a graphologist and capable of determining the character traits, abilities, passions and talents of the original scribe on the basis of a writing sample. That is, I do not engage in fortune-telling. For the practice of interpretation, I usually ask the person concerned to write the name and place of birth on a paper. I then tell them en passant based on a table on which day of the week they were born. Today graphology is a science, for which chairs have been established at the universities in Bonn and Würzburg. ${ }^{22}$

Apart from firmly denying that such a chair existed at Würzburg University, Marbe concluded in his answer that there existed no sharp boundaries between "graphologists who offer themselves in newspapers and write books and those who roam fairs and pubs." ${ }^{23}$ This was a stark attack on his colleagues, who in the same period tried to establish graphology as a science. In the case of Marbe, this is understandable because he firmly opted for a statistically based kind of experimental psychology and was in general doubtful regarding practices of "interpretation" (Deutung) or "intuition," which existed in some schools of psychology and graphology, especially in that of Ludwig Klages, whom he most probably had in mind in his criticism. ${ }^{24}$ Especially the emphasis of the personality of the psychologist as a trained interpreter cast doubt for Marbe on the scientificity of this kind of practice.

Even if by gathering all relevant court cases it would not be possible to measure the graphological underground of Weimar Republic. Therefore these three cases can only indicate that graphology could act as a reference point for gaining enough "scientific capital" (Bourdieu 1975) in order to legitimise the interpretation of handwriting as a scientifically valid practice. The graphologists emphasized that their practices were "scientific," and they underlined that they had a proper education or that they referred to books that were scientifically recognised. According to the police regulations (see last section), this was the prerequisite for them to be able to carry out their profession, since otherwise they would have been treated defrauders and punished. The fact that graphology could at least be practised to a certain degree as science provided the opportunity to use it as an argument for legitimising the own divinatory and characterological expertise. Graphology therefore provided an option to bridge a social and 
epistemic divide. The graphologists could rely on an existing demand for graphological expert opinions, which was an indicator of a more general demand for expert systems evidencing character types.

Marbe, a staunch defender of the ideals of scientificity, objectivity, and quantification, also published manuals for statistics and probability theory, and had been interested in the practice of graphological institutes before 1927. In his answer to the "Bezirksamt" Marbe emphasized, that there certainly existed interrelations between several "characters of handwriting."25

\section{Experimental Skills-Commentaries of Psychologists on Graphology}

In 1937 psychologist and philosopher Aloys Wenzl presented a systematic overview of the schools of scientific graphology. According to him, the main schools of contemporary psychology were that of Ludwig Klages, Robert Saudek, Max Pulver, Noeck Sylvus, and Broder Christiansen (Wenzl 1937: 23-40). Like Marbe, Wenzl also advocated a statistically based graphology and distrusted Klages' assessment of the level of form (Formniveau) by an unteachable competence of seeing (ibid.: 27) and questioned the usefulness of trying to integrate graphology into National Socialist racial science (ibid.: 112).

Marbe allows us to retrace the ambivalence of psychologists towards graphology. As a student of the Würzburg school of "Denkpsychologie" (thought psychology) represented by Oswald Külpe (1862-1915), Marbe was interested in a form of psychology that made thinking and thought the object of an objective and experimental science. He wanted to give the applied areas of psychology solid experimental footing and therefore was-like many of his colleagues-eager to mark the boundaries of psychology that in the 1920s, did not yet possess the "Diplomprüfungsordnung" of 1941, which created a framework of professional practice sanctioned by the state. ${ }^{26}$ However, Marbe by no means excluded graphology from psychology as part of the analysis of expression. In his papers there are documents that show the planning of a practical course in graphology during which he asked his students to examine a letter from Nietzsche. ${ }^{27}$ At the same time Marbe mistrusted the commercial exploitation of psychology of expression, which became fashionable in the 1920s. Besides the mostly accepted psychotechnical institutes there also existed a range of suspicious practices, among them those of graphological institutes. These institutes promised company owners to test the future employees and provided expertise on the loyalty of husbands or wives. 


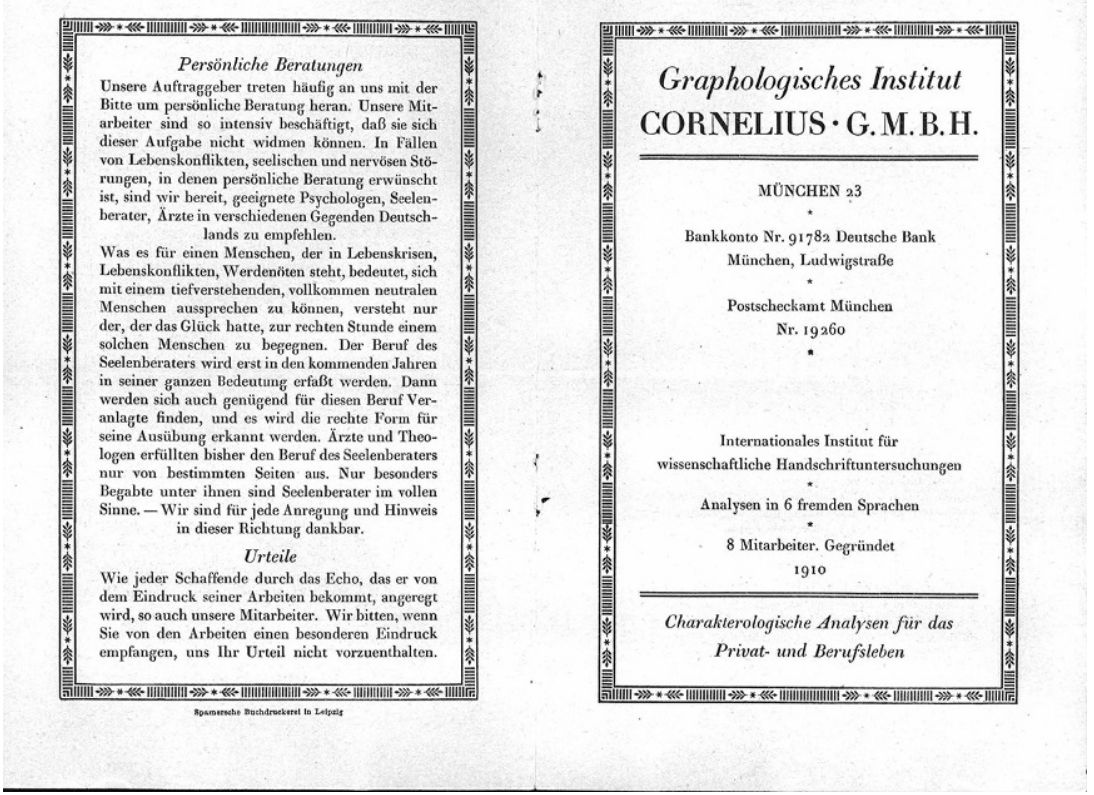

Fig. 1 First Page of a Leaflet of a Graphological Institute; Karl Marbe papers, Materialsammlung, Adolf-Würth-Zentrum, Würzburg.

In Fig. 1 you see an example: The "Graphologische Institut Cornelius GmbH", which existed since 1910 and offered, with absolute discretion, character sketches, analyses, and advisory analyses for 8, 15, and 20 Mark. The most expensive service was a comparative analysis of two handwriting samples, which were tested to determine whether the characters of the writers matched or not (a kind of dating agency for the early twentieth century).

Marbe choose the pseudonym Schlachter, and sent the same sample of his handwriting to eight of these institutes, the most expensive of which was the "Graphologische Beratungsstelle" (Graphological Consulting) of Elizabeth Worms in Cologne for 20.50 Mark, while grandmaster Ludwig Klages charged the comparatively small amount of 15.50 Mark. ${ }^{28}$ Even if Marbe appears to have been sceptical of graphological practice from the outset, the fact that he invested so much energy to test it-and that he included it in his teaching-indicates that he nevertheless remained openminded for the possibility that graphological expertise might provide a compelling option for character interpretation. Marbe's intervention therefore reveals a larger picture than just mistrust of dilettantes. At least in 1925 he invested time and money to scrutinize, if there existed a solid basis for graphology. In the end, however, the results of his investigations were 
rather disappointing. The character sketches he received were phrased in a way that they hardly managed to disguise their flattering intent. Here a testimony by L. Meyer, a Swiss graphologist, delivered July 1925:

The whole style of your writing suggests a sympathetic, benevolent personality, which, however, does not exactly know what she wants and, for example, does not give in due to weakness but rather to your peaceful nature-where she can reconcile it with her views and principles. $^{29}$

Even if Marbe had been initially interested in the graphological institutes, the results of his survey obviously did not convince him. In his answer to the Bezirksamt in 1927, in the case of the above-mentioned amateur graphologist, Marbe mentioned this research:

Today such investigations are not yet available, not even in the firstever beginnings, and the books of the so-called modern graphologists, including Mr. Klages, are rather based on opinions than on reasonably reliable, critical statistical experiences. Under these circumstances it is not surprising that recently, when I had one and the same handwriting assessed by numerous graphologists for a fee, I received apart from very general, commonplace phrases, contrary statements. ${ }^{30}$

Whenever you go through the archives of psychologists who dealt with further developing individual psychology in general or psychology of expression in particular, you will come across graphology. Marbe's stance towards graphology can thus be interpreted as a typical answer of psychology towards a more mundane expertise on human character. For example, the psychologist and important actor of the Institute for Applied Psychology in Berlin Otto Lipmann (1880-1933) argued in a paper "On the Applied Fields of Psychology"-presumably delivered in the 1920s-that the "general knowledge of human nature" (allgemeine Menschenkenntnis) could only come to some questionable generalizations. ${ }^{31}$ Even if some admirable judges of character-Lipmann names Goethe, Shakespeare, and Bismarck-demonstrated impressive skills, the identification of the laws of the prediction of individual behaviour was reserved for scientific psychology. In that context, graphology marked for Lipmann too the boundaries of science: was it possible to use handwriting to predict human behaviour? At the end of the day Lippman, like Marbe, only relied on statistics:

Only by scientific means will we be able to obtain information about the much disputed problem of graphology today-about the question whether and which psychological characteristics are documented in handwriting. The path that psychology must take to answer these and 
similar questions can only be that of statistics: we have to examine whether the majority of people who have a certain psychic quality also have a certain peculiarity of writing. ${ }^{32}$

Unlike Klages and Wieser, who relied on the personality of the interpreter, Marbe and Lipmann proposed to demarcate precisely the boundaries of science by de-personalizing the assessment of handwriting on the basis of statistics.

After World War II and the National Socialist era, during which graphology had been practised by many German psychologists, the sceptic reception of graphology as a scientifically unsound discipline became part of a more general narrative of the history of psychology during National Socialism. According to this narrative, psychology was suppressed during National Socialism and remained scientifically unproductive. The fact that graphology took an upswing at that time could then be seen exactly as an indication that the scientific principles of psychology during National Socialism were not in good shape. It can be seen as part of a more general post-war discourse on the purported "suppression" of psychology during National Socialism and alleged decline of science during that era: Ulfried Geuter and others have shown that this narrative of the decline of psychology during the Nazi period is misleading at the very least, and has served as an excuse for psychologists after WW II not to deal with the behaviour of psychologists during the Nazi era. ${ }^{33}$ Wilhelm Peters (1880-1963) was one of the few Jewish psychologists who returned to Germany after 1945. Being undenominational, Peters was nevertheless forced to retirement in 1933 due to his Jewish background and migrated to England. He then became a professor in Istanbul in 1937 and built up the psychological institute there. In 1952 he returned to Würzburg as emeritus (see Stock 2015). In an unpublished article about the "Misery of German Psychology" ${ }^{34}$ he openly criticised psychologists who had collaborated with the Nazi regime. From the perspective of Anglo-American methods (that is, statistical evaluation and experimental sophistication) he denounced the superiority of "speculative" approaches in German psychology, emerging in the first meeting of German psychologists after WW II in $1948 .{ }^{35}$ Especially the widespread use of graphology amongst psychologists marked for him the "misery" of German psychology, while social psychology was largely neglected. ${ }^{36} \mathrm{Pe}-$ ters had been an assistant to Marbe earlier (1910-1919) and so it is not surprising that he showed the same scepticism towards graphology. One could investigate further this rejection of interpretation (Deutung), which is a characteristic of the Würzburg School, for example for Maria Zillig (1896-after 1970) and Maria Schorn (1894/96-1968). Here it should suf- 
fice to refer to the examples quoted at the beginning, which show that also after 1945 graphology continued to be practiced as a science.

\section{Interferences}

In practice, one of the most important tasks of graphology was to determine and evaluate the regularity of a handwriting. Klages called this entity "Formniveau" (level of form), which reappeared in many guises as the characteristics of a person's handwriting that seemed to provide some insight into her or his inner stability. ${ }^{37} \mathrm{I}$ just give two examples from Roda Wieser's extensive research on prisoners' and policemen's handwritings. Wieser, a former student of Klages, was a certified expert for the interpretation of handwriting for the Vienna District Courts I and II, and worked for the Institute for Criminal Law and Criminalistics (Institut für die gesamte Strafrechtswissenschaft und Kriminalistik) on an irregular basis (Staudigl-Ciechowicz 2011: 34). Fig. 2 displays Wieser's reproduction of the handwriting of a painter's assistant, who had raped his own daughter. The man's handwriting is extremely irregular, providing insight into his inability to balance between his "will" (Wille) and his "drives" (Triebe):

Fig. 3, however, depicts the handwriting of a policeman, which though written in a fast hand, possessed in Wieser's view sufficient amount of regularity. For her this irregularity suggested a strong emotional life, whereas the regular handwriting proved that "a healthy will" (ein gesunder Wille) could control this emotionality:

These versions of graphology can be differentiated based upon the amount of trust given to the interpreter of the handwriting and the degree of experimental accuracy sought in the recording, preservation, and quantitative evaluation of the handwriting. As in other evidence techniques, the figure of the "genius," the inborn talent existed for graphology as well. According to Wieser, a graphological diagnosis was only feasible against the background of an a skill (Kunst) that was comparable to the medical diagnosis, which should be based on medical education, but at the same time and above all required intuition (Wieser 1933: 207). Likewise Friedrich von Rohden, a distinct supporter of racist scientific approaches to the human mind well before National Socialism, emphasized in his handbook on criminal biology that the Formniveau of the handwriting could only be captured intuitively, even if all aspects of conservational and experimental aspects of forensic investigation had been taken into account (Rohden 1933: 668).

Alongside psychology of expression, typological methods, or experimental methods, graphology provided an option for visualising the inner life. 


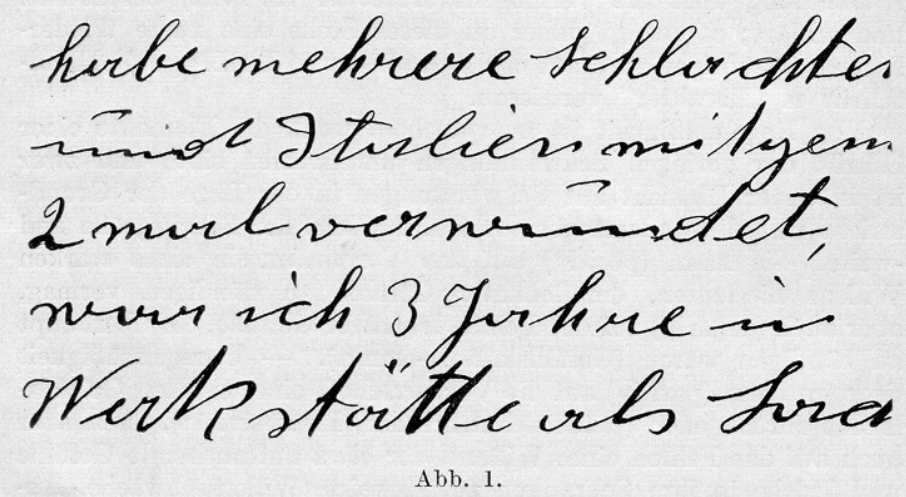

Fig. 2 Handwriting sample from Wieser's comparison between prisoner's and policemen's handwriting, Wieser 1933: 8 (Figure 1 in Wieser).

As becomes evident in the writings of Wieser, the central goal of this technique consisted in determining interferences in an otherwise homogeneous series of events mostly interpreted as a curve, and sometimes compared to the rhythm that existed in many natural processes (cf. Wenzl: 71, quoting Klages). With reference to the enthusiasm of experimental physiological research in the nineteenth century (cf. Schmidgen 2014) graphologists hoped that the movement of writing itself would form a kind of natural curve providing a basis for diagnosing the life of the soul. Friedrich von Rohden expressed this most succinctly:

In writing, nature itself provides us with a curve. Writing is created by movements that are registered by the pen on the paper in a similar way to the movements of the muscles on the kymographion drum in physiological experiments. (Rohden 1933: 664)

That is, in the view of Rohden graphology provided a natural curve. Unlike the more refined experimental methods this had the advantage of not requiring any artificial set-up. In this form graphology is nevertheless comparable in its epistemic structure to a range of other evidence techniques, which mostly used some form of automatic inscription device, such as kymograph that produced a curve.

In his article "What's in a Line?" Norton Wise has underscored the centrality of the curve in European sciences of the mid-nineteenth century with an emphasis on Berlin, where experimental physiologist Emil Du Bois-Reymond (1818-1896) made the curve an emblem of the Berlin Physical Society in 1845 (Wise 2010). As illustrated by Rohden's quote above, handwriting was re-interpreted against the background of the ubiq- 


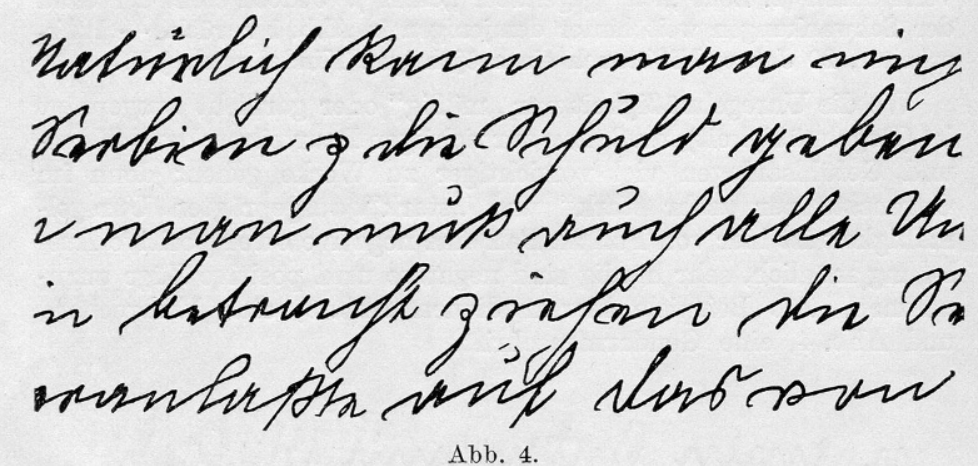

Fig. 3 Handwriting sample from Wieser's comparison between prisoner's and policemen's handwriting, Wieser 1933: 10 (Figure 4 in Wieser).

uity of the curve in science as the expression of nature: handwriting was a curve as well! In this sense, graphology as well as the subsequent development of lie detectors in the United States were all methods of interpreting the level of disturbances in a curve (Alder 2007). Publications in these fields are consequently filled with more or less exact curves. Henning Schmidgen has shown that since the mid-nineteenth century, brain-time experiments measuring ever-shorter reaction times have been an essential part of establishing a science of the human mind (Schmidgen 2014). For physio-psychologists of the nineteenth century such as Exner or Helmholtz it was quite common to assume the existence of the "unconscious"-for instance "unconscious conclusions"-and to see the reaction time experiments recorded on the basis of curves as part of the investigation of precisely this unconscious (ibid.: 42-43). Physiologically trained psychologists such as Hugo Münsterberg have further developed these methods and tried, for one thing, to increasingly improve the measuring methods and, then again, to create more natural experimental conditions (ibid.: 476-478). The curve here was the external sign of an internal automatism, which could thus provide information about internal processes beyond the will of the test person. Considering handwriting as a natural curve of inward expression thus meant returning to the psychophysiological tradition, and therefore graphologists tried to keep up with the reproduction technologies of physiologists (see for photography Hirschi 2016: 713; Schäfer 2016). This emphasis on experimental sophistication was understood as part of a boundary work that distances itself form amateur techniques of evidencing the psyche.

That is, we can distinguish different kinds of boundary work in the knowledge field of graphology: one strategy is the construction of the 
graphological genius guided by medical diagnosis. The heritage of experimental physiology emerges in the increasingly minute and exact curve, thus revealing the epistemic ideal of the direct readability of nature. Therefore this epistemology of graphology requires a clear distinction between the interpreter, and the sophistication of the material interpreted. Emphasising the abilities of the interpreter was mostly used for advocating the development of professional educational systems and laws prohibiting amateurs to practice the techniques in question. Highly sophisticated measurement techniques, in turn, were used to support arguments for the technical development of devices not be used by amateurs. In Wieser's work all these strategies of authorization are interlinked. She presented modern techniques of representation and evaluation of handwriting (photography, statistics, an elaborated conceptual framework) and at the same time emphasized the indispensable value of talent. This professionalization strategy could serve as a demarcation towards para-disciplines as well as towards amateurs. For actors who earned a part of their income from expert opinions in court this twofold demarcation stratetegy was particularly useful; it legitimized expertise as an expression of both private talent and official science. This kind of expert therefore emerges as talented scientist.

\section{The Police}

The special status of graphology among other border areas of psychological (or psychiatric) expression analysis is likewise reflected in the practices of control of the police. The Saxon interior ministry passed a decree in 1912 forbidding public demonstrations of clairvoyance. In 1921, the Saxon economics ministry inquired whether the 1912 decree applied to graphology and phrenology as well. ${ }^{38}$ The ministry held the view that while a scientific form of graphology and phrenology existed, thus legitimating its practice, at the same time a lot of fraud had to be thwarted. As a result the police had to determine if a given graphologist acted "scientifically" or fraudulent. The police in Saxony worked on corresponding guidelines, and in May 1934 the Leipzig Police Commissioner issued the "Guidelines for the Assessment of the Exercise of Graphology on a Recognised Scientific Basis" (Richtlinien für die Beurteilung einer Ausübung der Graphologie auf anerkannt wissenschaftlicher Grundlage). ${ }^{39}$ One solution of the Leipzig police was reference to an authority: A graphologist could prove his or her scientificity by an expert opinion either of Ludwig Klages himself-the "founder" of scientific graphology-or of one of his students. Likewise the expert opinion of graphologist Siegfried Römer of the Prussian Police 
Institute was mentioned in specific, because Klages had "officially authorised" him as his representative. At the same time, the Guidelines defined criteria for the non-scientific use of graphology. The criteria applying to Unwissenschaftlichkeit included: inadequacy of the graphologist's "level of education" (Bildungsniveau) or "personality" (Persönlichkeit); the graphologist's former practice of graphology, astrology, chiromancy, phrenology, cartomancy, and clairvoyance; his/her work for advertising (Reklame) or "grapological mailboxes" (graphologische Briefkästen) in newspapers; his/her use of "non-scientific brochures" (unwissenschaftliche Broschüren) to disseminate "graphological false doctrines" (graphologische Irrlehren) and to recruit customers; or his/her assessment of more than just "character." ${ }^{40}$ It is evident that while the definition of graphology's scientificity in these guidelines was rather concrete and clear, much vagueness was involved when it came to define which practice was non-scientific. The Guidelines were intended to help with the implementation of a police regulation (Polizeiverordnung) published on 10th April 1934. ${ }^{41}$ Said decree stipulated that police officers should intervene against graphologists, "if they cannot demonstrate that they only interpret character and that they were trained by a scientifically recognised personality." ${ }^{2}$

The expert opinions of Marbe and Hellwig as well as the police commentaries in Leipzig make clear that graphology had a mixed status. For one thing, it was considered a practice of quacks that should be forbidden. Then again, graphology was considered a scientific discipline, and formal training for graphologists was initialised.

In addition to controlling graphology practices, police officers reflected on using graphology themselves. One of the most accepted forms of the analysis of handwriting samples was the collection of handwritings established at Berlin police headquarters, led by Hans Schneickert (1876-1944), chief of the Berlin police records department, from 1914 to 1927. In Berlin the handwriting samples were not used as the basis of a character analysis but to compare two or more handwriting samples with each other. Schneickert, who wrote an important handbook on interrogation technique, was convinced of the practical usefulness of graphology as well. In 1942 he underlined its status as an "art" as opposed to a "science." He stressed that "science" and "art" were the cornerstones of any psychological evaluation of an expression of the soul (Schneickert 1942: 205).

We can discern a growing interest in graphology as character diagnosis in the 1930s both, within the psychological practices of the police as well as within the military (cf. Geuter 2000). Hence, for example, the most influential interrogation technique handbooks published before 1933, included new chapters on graphology in later editions. One of these handbooks was that of Hellwig, first issued in 1927 (Hellwig 1927). In the 1944 edition, 
Hellwig added a chapter on graphology, which also made it into the edition of 1951 (Hellwig 1944; 1951: 223-233). There he basically reproduced the position of Munich based public prosecutor Franz Meinert on graphology, who had written another influential handbook on interrogation technique (Meinert 1939). Meinert believed that analysing the handwriting allowed to draw conclusions about the "resistance energy" (Widerstandsenergie), "resistance intelligence" (Widerstandsintelligenz), and the "emotional life" (Gefühlsleben) of a suspect (Hellwig 1944: 161). In the authoritarian scheme of Meinert's interrogation technique this information provided an important starting point for the interrogation, given that one of the most important tasks was to estimate the amount of emotional pressure a police officer could exercise during an interrogation before the suspect abandoned her or his will to resist. Hence personality assessment was crucial for Meinert, and graphology was one of the means he recommended for police officers. Meinert's use of graphology is deeply authoritarian. This is a symptom of his general authoritarian understanding of police interrogation, which at least implies sympathy with torture as Nicola Willenberg demonstrates. She points out that Meinert's reflections on interrogation technique and its implicit legitimation of the abuse of state authority were still published unmodified in the 1948 edition and only changed in 1956 (Willenberg 2013: 75-76). For Meinert, graphology was a legitimate tool within an ensemble of strategies for assessing the suspect, ultimately forcing him to submit to the authority of the officer.

\section{Conclusion}

In her book about German traditions of parapsychology and psychical research, Heather Wolffram proposed to call these fields of knowledge "border sciences," because they continually stimulated a debate on legitimate objects and procedures of science (Wolffram 2009: 17; cf. Wolffram 2018) and even if they have been pursued by established scientists opened up a space of scientific agency for amateurs. It is exactly through an analysis of these border sciences (or "fringe sciences," ibid.: 18), as Wolffram contends, that one could study processes of disciplinarisation and professionalisation. Graphology has not been a border science in the sense of parapsychology or psychic research, since it mostly did not deal with objects, whose very existence was questioned, or with forces unknown to science (with the exception of "meta-graphology" presentend in Zeitschrift für Parapsychologie during the 1920s, Marcinowski 1928). Secondly, graphology, mostly did not propose epistemic techniques that were controversial in themselves, but 
in their applications and inferences. Graphology can rather be described within the framework of Thomas Gieryn's concept of boundary work, since it formed the starting point to continually make explicit and negotiate the boundaries of legitimate scientific practice (Gieryn 1983). By claiming that every movement of expression could in one way or another be traced back to some cause or motivation in humans, graphology has been part of the large field of methods that sought to infer inner motivations and character traits from external features.

One aspect of this article concerns the status of expert systems for evaluating personality and character. Within the psy-disciplines and other fields of knowledge since the late nineteenth century this practical application has been the object of ongoing negotiation. A network of different experts has legitimised itself with regard to each other and to non-experts, while the latter status had to be defined either in epistemic terms or by social standing and education. Given the precarious-epistemic and social-existence of graphology compared to psychiatry or medicine, it is not surprising that the graphologists Caspar Hirschi analysed in his compelling article about the Dreyfus affair presented their expertise in the style of assertive rigidity (Hirschi 2016). The same applies for expert statements from psychology of testimony (Aussagepsychologie), and it might be noted in general that expert testimonies in court, especially from not yet firmly established disciplines, tend to have a rather assertive style. That style differs significantly from texts by the same actors published in scientific journals in their own field.

Graphology's use as an interpretation of the character or personality remained controversial. One can agree with Hirschi that its use in this sense was rather relevant for the economic sector and continued to attract actors, which used these techniques in areas regarded as charlatanry by official, institutionalised science. Epistemologically graphology remained just as questionable as the connection with the fairground, and the commercial greed of graphologists let it appear socio-economically objectionable. This dubious nature of graphology repeatedly raised the question of correct methods and appropriate subject positions of character interpretation, thus generally unfolding a subject-political and epistemic conflict about the possibility and scientific form of character interpretation in general.

Graphology relied on a very common cultural technique and on very widespread traces of that practice: on writing and its products. This cultural technique has stimulated systems of interpretation long before graphology aimed to use these systems in order to establish a science. I argue that this has been possible on something that Ludwik Fleck has called a "pre-idea," some rather vague and widespread idea, that structures practices of research without necessarily being made explicit (Fleck 
1979). In this case, a quite relevant pre-idea was the belief that in some form the writer's mind would be present or readable in the handwriting. This concept facilitated interpretation systems of writing and scripture that assembled heterogeneous actors sharing that same pre-idea. Various systems of proof, research, and different subject constructions could now be mobilised to claim the legitimacy of interpretations and of actors giving these interpretations. With the case-study on graphology I want to point to a much larger field of these zones of boundary work, which could be analysed analogically: it is a typical feature of psy-disciplines (and also other disciplines such as sociology) that they relate to or even build upon every day practices, giving them a scientific explanation: the interpretation of facial expressions, of dreams, or of interactions. Therefore, it must be considered a characteristic feature of these disciplines that they are situated between scientific and non-scientific actors, making it necessary to legitimise and explain the benefit and structure of these new scientific explanations of all too well-known phenomena. It was therefore necessary to make the norms of the own practice explicit and impose them as legitimate. However, by assembling these diverse actors of different social and epistemic standing, graphology stimulated a discourse on scientificity comparable to the discourse on the border sciences Wolffram describes.

In this article I have focused on three types of contributions to graphology: that of the actors on the margins of official science; that of acknowledged psychologists developing further and questioning the techniques of graphology, and that of the police. For a more comprehensive assessment, the discussions in para-psychology could further enrich this analysis. Graphology was a scientific field whose hegemony was gained by reference to scientificity, or in terms of Pierre Bourdieu: "scientific capital" (Bourdieu 1975). Psychologists, psychiatrists, police officers, jurists, and philosophers thereby presented different epistemic ideals, which in their eyes should form the basis of legitimate practices in graphology. The one side choose to put the emphasis on the valorisation of the interpreter of the handwriting. Thus, Ludwig Klages, Roda Wieser, or Friedrich von Rohden subscribed to an understanding of graphology that considered the ability to interpret and characterize handwriting a talent. As described above, this professionalization strategy composed of personal talent and institutional authorization was particularly suitable for experts in court. In this way, they were able to present themselves as irreplaceable and scientifically legitimized at the same time. For university psychologists, the emphasis on personal talent was not necessary, but the emphasis on scientific procedures was important: Karl Marbe, Otto Lipmann, or Aloys Wenzl emphasised the necessity of a de-personalized technical apparatus-either a statistical evaluation or a sophisticated experimental technique-as pre- 
supposition for any legitimate graphological practice. Both demarcation strategies served as a boundary work separating proper science from nonscience, either from the practice charlatans at the fairground, or from the practices of commercial institutes for vocational guidance, couple counselling, and consulting for companies.

The view of the police on either the charlatans or its own use of graphology reflected a more widespread user knowledge compared to academia. As usual in interrogation techniques, police officers would acquire knowledge from psychology or other disciplines, but then emphasise the value of experience (Erfahrenheit), made in practice (cf. for example Rathsam 1937; Gennat 1929; Salaw 1935). For them, graphology was part of a wider field of techniques to evaluate the personality of witnesses or suspects during interrogations, which became more fashionable during a general reevaluation of methods to analyse expression during the 1930s and 1940s.

The perspective of the "charlatans" adds to the widespread use of graphology by graphological institutes. As the court cases demonstrate, there existed a widespread demand and willingness to accept the services of persons claiming an expertise in the interpretation of handwriting. These persons could choose between different options to legitimise themselves. Firstly they relied on the values of science and used the associated rhetoric, building "scientific institutes" for graphology and referring to books and educational bio-histories which, in their eyes, could count as scientific. They could, secondly, underscore the value of their personality as interpreters and aim to choose environments and atmospheres within which the impression of their personality would be more pronounced. One can expect that in most cases their strategies of social legitimisation might have been a mixture of both.

Graphology as an insight into character, the predispositions, and the type of human beings never lost contact to everyday practices and the esoteric circles of scientific experts, thereby generating a particular need for the experts to distance themselves from what could not count as legitimate knowledge. As indicated by the widespread use in companies, graphology was also part of a growing interest in controlling or categorising people. Carlo Ginzburg has therefore interpreted these ever-more refined forms of sign-reading as symptom of a growing density of social control, which was also reflected by refined practices of categorising people, for example through fingerprints (Ginzburg 2002). Graphology as an offer to know the inner life of suspects, as an option for enterprises to test their employees, and as daily practice of character analysis on fairgrounds and in pubs played a part in this field of social control. The desirability of a fast, safe, and natural method of determining the character of a person with certainty also points to a transformation in the social structure of work, in which the hu- 
man factor has become increasingly important as a means of production. It was precisely this field that was structured by the competition of amateur graphologists, psychologists, psychiatrists and commercial institutes who, after the rise of test psychology during World War I, wanted to skim off some of the economic potential. The psychologists considered in this paper-Karl Marbe, Aloys Wenzl, William Stern, Otto Lipmann, Roda Wieser and Ludwig Klages-were ambivalent regarding this economic exploitation of their professional competence: for one thing, they needed proof for the usefulness of psychology; then again, they underscored the values of disinterestedness and objectivity, which could appear to be threatened. The amateurs and commercial institutes felt the inverse challenge and nevertheless wanted to present themselves as scientific actors in a situation of economic profit. They needed the symbolic power of science just as science needed the economization of its epistemic techniques while at the same time distancing itself from them. It was exactly because of this that the negotiation of epistemic ideals, techniques, and a boundary work between science and non-science became so important.

\section{Archival Sources}

- Archives of IGPP, Freiburg, papers of Albert Hellwig.

- Archives of Adolf-Würth-Zentrum, Würzburg University, papers of Karl Marbe.

- Sächsisches Staatsarchiv, Staatsarchiv Leipzig, 20031 Polizeipräsidium Leipzig.

- Schweizerisches Literaturarchiv, Bern, papers of Franziska Baumgarten.

- Archives of National Libary of Jerusalm, papers of Otto Lipmann, ARC. 4* 1725 .

Funding Open Access funding provided by Projekt DEAL.

Open Access This article is licensed under a Creative Commons Attribution 4.0 International License, which permits use, sharing, adaptation, distribution and reproduction in any medium or format, as long as you give appropriate credit to the original author(s) and the source, provide a link to the Creative Commons licence, and indicate if changes were made. The images or other third party material in this article are included in the article's Creative Commons licence, unless indicated otherwise in a credit line to the material. If material is not included in the article's Creative Commons licence and your intended use is not permitted by statutory regulation or exceeds the permitted use, you will need to obtain permission directly from the copyright holder. To view a copy of this licence, visit http://creativecommons. org/licenses/by/4.0/. 


\section{Endnotes}

1 Archives of Institute for Frontier Areas of Psychology and Mental Health (IGPP), Freiburg, papers of Albert Hellwig, X, 17-Gutachten Hellseher, expert testimony of Hellwig, $7^{\text {th }}$ December 1924.

2 Ibid.

3 Sächsisches Staatsarchiv, Staatsarchiv Leipzig, 20031 Polizeipräsidium Leipzig.

4 Cf. Ploog (2016), to give just one example. Ploog provides a short history of graphology, in which he too names Ludwig Klages as its founder (ibid.: 16).

5 Cf. Michon (1875); Hirschi (2016).

6 Schneickert valued his contributions, claiming that Pophal had laid the foundations of a "bewegungsphysiologische Graphologie," a kind of graphology based on the analysis of the movements during writing (Schneickert 1942: 205).

7 Schweizerisches Literaturarchiv, Bern, Switzerland, Franziska Baumgarten papers, B-4ISR, letter from Dr. Pokorny, Tel Aviv, 23 ${ }^{\text {rd }}$ May 1950.

8 Therefore Bobertag strongly recommended success controls of graphological evaluations (Bobertag 1929: 17-18).

9 Throughout the National Socialist era the more "intuitive" approaches were criticized, and more statistically procedural forms of graphology that were critically opposed to National Socialist racial science were represented, cf. (Wenzl 1937).

10 See for the discussion about forensic psychology with a focus on William Stern, Paul Plaut, and Albert Hellwig (Wolffram 2015).

11 Archives of IGPP, Bestand 10/4, papers of Albert Hellwig, X, 17-Gutachten Hellseher, $7^{\text {th }}$ December 1924.

12 Ibid.

13 Archives of IGPP, Bestand 10/4, papers of Albert Hellwig, I, 4.4-Fall Maria Hessel: This file contains notes on a session with two female clairvoyants in a prison-an experimental situation chosen because any contact to other persons should be excluded.

14 Ibid., X, 17-Gutachten Hellseher, $7^{\text {th }}$ December 1924.

15 Ibid., pp. 17-19.

16 Ibid., letter from $13^{\text {th }}$ November 1924.

17 Ibid.

18 Ibid., letter from $17^{\text {th }}$ November 1924.

19 The most important research on Marbe stems from Mülberger (1994; 2009).

20 Ibid., I, 4.4-Fall Maria Hessel, "Bericht über die Hauptverhandlung," $4^{\text {th }} J u l y ~ 1928$, cf. Marbe (1927).

21 Ibid.

22 Archives of Adolf-Würth-Zentrum, Würzburg University, papers of Marbe, K1 3019516, Bezirksamt an das Rektorat der Universität Würzburg, Wolfach, $10^{\text {th }}$ February 1927.

23 Ibid., Marbe to Bezirksamt Wolfach, $19^{\text {th }}$ Feburary 1927.

24 For a systematic overview over the schools of graphology cf. Wenzl (1937).

25 Ibid.

26 In the history of psychology, the establishment of the "Diplomprüfungsordnung" in 1941 is judged to be a major event in the professionalization of the discipline as it facilitated a formalized professional training; cf. Geuter (2000: 39-44).

27 Archives of Adolfs-Würth-Zentrum, Würzburg University, papers of Marbe, M[aterial].

28 These were in specific: "Seminar für Ausdruckskunde" (München), "Graphologisches Institut H. Gernstner" (Wolfegg), "Institut für wissenschaftliche Graphologie" (München), L. Meyer (Maienfeld bei Ragaz, Switzerland), "Graphologisches Institut" (Köln), Ludwig Klages (Kilchberg am Zürisee, Switzerland), "Institut zur Förderung der wissenschaftlichen Handschriftenbeurteilung G.m.b.H.” (Berlin), "Institut für graphologische Forschung" (München), "Graphologische Beratungsstelle” (Köln). 
Archives of Adolf-Würth-Zentrum, Würzburg University, papers of Marbe, U2, part 1. Marbe to Bezirksamt Wolfach, 19th February 1927, Archives of Adolf-Würth-Zentrum, Würzburg University, papers of Marbe, K1 3019516, correspondence with Rossner.

Papers of Otto Lipmann, National Library of Israel, Jerusalem, ARC. 4* 1725, Vorträge 2 (23-59), paper "Anwendungsgebiete der Psychologie", p. 4.

Ibid., p. 6.

See especially Geuter (2000); Ash (2002: 231); Prinz (1985).

Archives of Adolf-Würth-Zentrum, Würzburg University, papers of Wilhelm Peters, WN 10.

Schweizerisches Literaturarchiv, Bern, papers of Franziska Baumgarten, B-4-NATI.

Ibid.: "German psychology of personality and character has been embedded in philosophical speculation, and even the application of character analysis to personal 'counselling' does not abstain from such speculation. Graphology is considered as an established science, social psychology-in the Western sense of the term-is almost entirely neglected, psychologists having worked with the armed forces are abundant in number and weight. All work in applied psychology, however, is handicapped by lack of readiness and ability to submit raw empirical data to scientific check."

Klages (1920); cf. Lück (1987: 104) and Geuter (2000).

SächsStA, StA- L, 20031 Polizeipräsidium Leipzig, PP-V 3990, Bl. 110.

Ibid., Bl. 95, the guidelines were published on $19^{\text {th }}$ May 1934.

Ibid.

Ibid. p. 94.

Ibid.

\section{References}

Alder, Ken 2007. The Lie Detectors. The History of an American Obsession. New York: Free Press.

Ash, Mitchell 2002. Psychologie. In: Franz-Rutger Hausmann (ed.). Die Rolle der Geisteswissenschaften im Dritten Reich 1933-1945. München: Oldenbourg: 229-264.

Bindman, David 2002. Ape to Apollo. Asthetics and the Idea of Race in the 18th Century. London: Reaktion Books.

Binet, Alfred 1903. La graphologie et ses révélations sur le sexe, l'âge et l'intelligence. L'Année psychologique (10): 179-210. https://doi.org/10.3406/psy.1903.3547.

Bobertag, Otto 1929. Ist die Graphologie zuverlässig? Heidelberg: Niels Kampmann Verlag.

Borck, Cornelius 2015. Hirnströme. Eine Kulturgeschichte der Elektroenzephalographie. Göttingen: Wallstein.

Bornemann, Aenne and Ernst 1948. First Post-War Meeting of the Professional Association of German Psychologists (Berufsverband Deutscher Psychologen). American Psychologist 3 (2): 59-59.

Bourdieu, Pierre 1975. The Specificity of the Scientific Field and the Social Conditions of the Progress of Reason. Social Science Information 14 (6): 19-47.

Bracken, Helmut von 1952. Recent Trends in German Psychology. The Journal for General Psychology 47 (2): 165-179.

Braunstein, Jean-François 1998. Antipsychologisme et philosophie du cerveau chez Auguste Comte. Revue internationale de philosophie 52 (203): 7-28.

Courtine, Jean-Jaques and Claudine Haroche 1994. Histoire du visage. Exprimer et taire ses émotions (XVIe-début XIXe siècle). Paris: L'édition de poche.

Fleck, Ludwik 1979. Genesis and Development of a Scientific Fact. Chicago: University of Chicago Press.

Gennat, Ernst 1929. Vernehmungen - Kriminalistische Strategie und Taktik. Kriminalistische Monatshefte 2 (5): 101-105. 
Geuter, Ulfried 1983. Der Nationalsozialismus und die Entwicklung der deutschen Psychologie. In: Steffen Harbordt (ed.), Wissenschaft und Nationalsozialismus. Zur Stellung der Staatsrechtslehre, Psychologie, Naturwissenschaft und der Universität zum Nationalsozialismus. Berlin: TU Berlin: 82-100.

Geuter, Ulfried 1985. Nationalsozialistische Ideologie und Psychologie. In: Michtell Ash and Ulfried Geuter (eds.). Geschichte der deutschen Psychologie im 20. Jahrhundert. Opladen: Westdeutscher Verlag: 172-200.

Geuter, Ulfried 2000. The Professionalization of Psychology in Nazi Germany. Cambridge: Cambridge University Press.

Gieryn, Thomas 1983. Boundary-Work and the Demarcation of Science from Non-Science. Strains and Interests in Professional Ideologies of Scientists. American Sociological Review 48 (6): 781-795.

Ginzburg, Carlo 2002. Spurensicherung. Die Wissenschaft auf der Suche nach sich selbst. Berlin: Wagenbach.

Goldstein, Jan 2005. The Post-Revolutionary Self. Politics and Psyche in France, 1750-1850. Cambridge, MA: Harvard University Press.

Hacking, Ian 1986. Making up People. In: Thomas C. Heller, Morton Sosna and David E. Wellbery (eds.). Reconstructing Individualism. Stanford: Stanford University Press: $222-236$.

Hacking, Ian 1991. The Making and Molding of Child Abuse. Critical Inquiry 17 (2): 253-288.

Hacking, Ian 1999. Historical Meta-Epistemology. In: Wolfang Carl and Lorraine Daston (eds.). Wahrheit und Geschichte. Ein Kolloquium zu Ehren des 60. Geburtstages von Lorenz Krüger. Göttingen: Vandenhoeck \& Ruprecht: 53-77.

Hacking, Ian 2002. Historical Ontology. London: Harper University Press.

Hellwig, Albert 1924. Okkultismus und Strafrechtspflege. Über die Verwendung von Hellsehern bei Aufklärung von Verbrechen. Bern: Bircher.

Hellwig, Albert 1927. Psychologie und Vernehmungstechnik bei Tatbestandsermittlungen: eine Einführung in die forensische Psychologie für Polizeibeamte, Richter, Staatsanwälte, Sachverständige und Laienrichter. Berlin: Langenscheidt.

Hellwig, Albert 1929. Okkultismus und Verbrechen. Eine Einführung in die kriminalistischen Probleme des Okkultismus für Polizeibeamte, Richter, Staatsanwälte, Psychiater und Sachverständige. Berlin: Langenscheidt.

Hellwig, Albert 1944 [1927]. Psychologie und Vernehmungstechnik bei Tatbestandsermittlungen. Eine Einführung für Polizeibeamte, Richter, Staatsanwälte, Sachverständige und Laienrichter. Berlin: Arthur Sudau.

Hellwig, Albert 1951 [1927]. Psychologie und Vernehmungstechnik bei Tatbestandsermittlungen. Vierte vermehrte und verbesserte Auflage. Stuttgart: Ferdinand Enke.

Hirschi, Caspar 2016. Dreyfus, Zola und die Graphologen. Vom Expertenversagen zum Intellektuellensieg. Historische Zeitschrift (303): 705-747. https://doi.org/10.1515/hzhz2016-0462.

Hofstätter, Peter 1940. Die diagnostische Bedeutung der Dunkelschrift. Leipzig: Barth.

Jaeger, Siegried 1985. Zur Herausbildung von Praxisfeldern der Psychologie bis 1933. In: Mitchell Ash and Ulfried Geuter (eds.). Geschichte der deutschen Psychologie im 20. Jahrhundert. Ein Überblick. Opladen: Westdeutscher Verlag: 83-112.

Jung, Kathrin 2000. Die Geschichte des Psychologischen Instituts der Universität Heidelberg in den Jahren 1933 bis 1980. Diploma thesis, University of Heidelberg.

Klages, Ludwig 1920 [1917]. Handschrift und Charakter. Gemeinverständlicher Abriss der graphologischen Technik. Zweite wesentlich erweiterte Auflage. Leipzig: Ambrosius Barth.

Koppe, Friedrich 1962. Der Psychologe im polizeilichen Ermittlungsverfahren. In: Günther Blau and Elisabeth Müller-Luckmann (eds.). Gerichtliche Psychologie. Aufgabe und Stellung der Psychologen in der Rechtspflege. Neuwied am Rhein/Berlin-Spandau: Hermann Luchterhand Verlag: 99-109.

Kracauer, Siegfried 1971 [1930]. Die Angestellten. Aus dem neuesten Deutschland. In: Siegfried Kracauer. Soziologie als Wissenschaft. Der Detektiv-Roman. Die Angestellten. Edited by Karsten Witte. Frankfurt am Main: Suhrkamp. 
Lebovic, Nitzan 2013. The Philosophy OfLife and Death. Ludwig Klages and the Rise of a Nazi Biopolitics. New York: Palgrave Macmillan.

Lersch, Philipp 1932. Gesicht und Seele. Grundlinien einer mimischen Diagnostik. München: Reinhardt.

Leys, Ruth 2010. How Did Fear Become a Scientific Object and What Kind of Object is it? Representations 110 (1): 66-104.

Lück, Helmut 1987. Sozialgeschichte der Psychologie. Eine Einführung. Opladen: Leske + Budrich.

Marbe, Karl 1927. Eignungsprüfungen für Rutengänger. München/Berlin: Oldenbourg.

Marcinowski, Johannes 1928. Intuitive Charakterdiagnosen. Beobachtungen an einer Hellwissenden. Zeitschrift für Parapsychologie 13 (11): 645-652.

Marcinowski, Johannes 1926. Der Okkultismus als Weltanschauungsproblem. Zeitschrift für Parapsychologie (11): 680-695.

Meinert, Franz 1939. Vernehmungstechnik. Lübeck: Verlag für polizeiliches Fachschrifttum.

Michon, Jean-Hippolyte 1875. Système de graphologie. L'art de connaître les hommes d'après leur écriture. Paris: Lecuir.

Mülberger, Annette 1994. La aportación de Karl Marbe a la psciologia. PhD Thesis, University of Barcelona.

Mülberger, Annette 2009. Karl Marbe und die Anwendung der Psychologie im Rechtswesen vor dem ersten Weltkrieg. In: Mathias Schmoeckel (ed.). Psychologie als Argument in der juristischen Literatur des Kaiserreichs. Baden-Baden: Nomos: 133-153.

Nicolas, Serge, Bernard Andrieu, Rasyid Bo Santioso, Romain Vincent and David J. Murray 2015. Alfred Binet and Crépieux-Jamin. Can Intelligence be Measured Scientifically by Graphology? L'Année psychologique 115 (1): 3-52.

Ploog, Helmut 2016. Handschriften deuten. Die Persönlichkeit im Spiegel der Schrift. Mit vielen Beispielen prominenter Persönlichkeiten. Hannover: Humboldt.

Pophal, Rudolf 1949. Die Handschrift als Gehirnschrift. Die Graphologie im Lichte des Schichtgedankens. Rudolstadt: Greifenverlag.

Preyer, William 1928. Zur Psychologie des Schreibens mit besonderer Rücksicht auf individuelle Verschiedenheiten der Handschriften. Leipzig: Leopold Voss.

Prinz, Wolfgang 1985. Ganzheits- und Gestaltpsychologie im Nationalsozialismus. In: Carl Graumann (ed.). Psychologie im Nationalsozialismus. Berlin: Springer: 89-111.

Rathsam, Berta 1937. Noch einmal: psychologische Sachverständige? Kriminalistische Monatshefte 11 (1): 5-9.

Rohden, Friedrich von 1933. Methoden der Kriminalbiologie. Berlin: Urban \& Schwarzenberg.

Rupnow, Dirk, Veronika Lipphardt and Christina Wessely 2008. Einleitung. In: Dirk Rupnow, Veronika Lipphardt, Jens Thiel and Christina Wessely (eds.). Pseudowissenschaft. Konzeptionen von Nichtwissenschaftlichkeit in der Wissenschaftsgeschichte. Frankfurt: Suhrkamp: 7-20.

Salaw, Hans 1935. Psychologische Gesichtspunkte zur Vernehmungspraxis. Kriminalistische Monatshefte 9 (4): 79-83.

Schäfer, Armin 2016. Graphology in German Psychiatry (1870-1930). History of Psychiatry 27 (3): 307-319.

Schmidgen, Henning 2014. Hirn und Zeit. Die Geschichte eines Experiments, 1800-1950. Berlin: Matthes \& Seitz.

Schmölders, Claudia 1995. Das Vorurteil im Leibe. Eine Einführung in die Physiognomik. Berlin: Akademie.

Schneickert, Hans 1942. Läßt sich die Graphologie naturwissenschaftlich begründen? Deutsche Zeitschrift für gerichtliche Medizin 35 (4): 205-210.

Schneider, Tobias 2001. Ideologische Grabenkämpfe. Der Philosoph Ludwig Klages und der Nationalsozialismus (1933-1938). Vierteljahrshefte für Zeitgeschichte 49 (2): 275-294.

Staudigl-Ciechowicz, Kamila 2011. Zur Entstehung der Wiener Kriminologie und Kriminalistik in der 1. Republik. Journal on European History of Law 2 (1): 29-35.

Stern, William 1931. Das Psychologische Institut der Hamburgischen Universität in seiner gegenwärtigen Gestalt. Dargestellt aus Anlaß des XII. Kongresses der Deutschen Gesellschaft für Psychologie in Hamburg 12. bis 16. April 1931 von dem Direktor und den Mitarbeitern. Leipzig: Ambrosius Barth. 
Stock, Armin 2015. Peters, Wilhelm. In: Uwe Wolfradt, Elfriede Billmann-Mahecha, and Armin Stock (eds). Deutschsprachige Psychologinnen und Psychologen. Wiesbaden: Springer: 350-352.

Utitz, Emil 1925. Charakterologie. Berlin-Charlottenburg: Pan-Verlag Rolf Heise.

Vars, Émille 1874. Histoire de la graphologie. Paris: Dentu.

Wenzl, Aloys 1937. Graphologie als Wissenschaft. Leipzig: Quelle \& Meyer.

Wieser, Roda 1933. Die Verbrecherhandschrift. Volume II: Die Handschrift der Sexualverbrecher. Wien: Springer.

Willenberg, Nicola 2013. "Ohne oder mit $\$ 136$ a darf und wird es in Deutschland nie wieder eine Anwendung unzulässiger Vernehmungsmethoden geben”. Zur deutschen juristischen Diskussion des Folterverbots vom 19. Jahrhundert bis in die 1950er Jahre. In: Karsten Altenhain, Reinhold Göring, and Johannes Kruse (eds.). Die Wiederkehr der Folter? Interdisziplinäre Studien über eine extreme Form der Gewalt, ihre mediale Darstellung und ihre Ächtung. Göttingen: V \& R Unipress: 59-104.

Wise, Norton 2010. What's in a Line? In: Moritz Epple (ed.). Science as Cultural Practice. Vol. 1: Cultures and Politics of Research from the Early Modern Period to the Age of Extremes. Berlin: Akademie: 61-102.

Wolffram, Heather 2009. The Stepchildren of Science. Psychical Research and Parapsychology in Germany, c. 1870-1939. Amsterdam: Rodopi.

Wolffram, Heather 2015. "God Save us from Psychologists as Expert Witnesses". The Battle for Forensic Psychology in Early Twentieth-Century Germany. History of Psychology 18 (4): 337-352.

Wolffram, Heather 2018. Forensic Psychology in German-Speaking Europe. Witnessing Crime, 1880-1939. Cham: Palgrave Macmillan.

Wyhe, John van 2002. The Authority of Human Nature. The Schädellehre of Franz Joseph Gall. The British Journal for the History of Science 35 (1): 17-42.

Publisher's Note Springer Nature remains neutral with regard to jurisdictional claims in published maps and institutional affiliations.

\section{Laurens Schlicht}

Institut für Romanische Kulturwissenschaft und Interkulturelle

Kommunikation

Universität des Saarlandes

66123 Saarbrücken

Germany

laurens.schlicht@uni-saarland.de 